\title{
A Chinese patient with $11 \beta$-hydroxylase deficiency due to novel compound heterozygous mutation in CYP11B1 gene: a case report
}

Xianxian Yuan ${ }^{1}$, Lin Lu ${ }^{1 *}$, Shi Chen ${ }^{1}$, Jun Jiang ${ }^{2}$, Xiangqing Wang ${ }^{1}$, Zhihui Liu' ${ }^{1}$, Huijuan Zhu' ${ }^{1}$, Hui Pan ${ }^{1}$ and Zhaolin $\mathrm{Lu}^{1}$

\begin{abstract}
Background: Congenital adrenal hyperplasia (CAH) resulting from steroid $11 \beta$-hydroxylase deficiency (11 $\beta$-OHD) is caused by mutations in the CYP11B1 gene. It is the second major form of CAH associated with hypertension and hypopotassemia. The aim of this study was to provide a genetic analysis of $11 \beta-\mathrm{OHD}$ in a Chinese family.

Case presentation: A 19-year-old Chinese man was clinically diagnosed with $11 \beta-\mathrm{OHD}$. His initial clinical manifestations included precocious puberty, hyperpigmentation, hypertension, and hypopotassemia. The patient had taken an overdose of dexamethasone $(0.75 \mathrm{mg} / \mathrm{d})$ for more than 10 years before finally developing iatrogenic Cushing's syndrome. Our aim was to perform a molecular diagnosis of his family. Mutations in the CYP11B1 gene of the patient and his parents were examined using polymerase chain reaction (PCR) resequencing. Additionally, to predict the possible effects of novel mutations on the structure and function of $11 \beta$-hydroxylase, these mutations were analyzed by MutationTaster software. Two novel pathogenic mutations were found in the CYP11B1 gene: a heterozygous in-frame insertion deletion mutation c.1440_1447delinsTAAAAG in exon 9 inherited from the father and a heterozygous mutation c.1094_1120deITGCGTGCGGCCCTCAAGGAGACCTTGC (p.364_372del) in exon 6 inherited from the mother.

Conclusions: A clear genetic diagnosis can be made by analyzing the functional and structural consequences of CYP11B1 gene mutations that lead to 11ß-OHD. Because the dosage of glucocorticoid should be adjusted to minimize the risk of iatrogenic Cushing's syndrome, clinical follow-up should be conducted with these patients.
\end{abstract}

Keywords: 11ß-hydroxylase deficiency, CYP11B1 gene mutation, latrogenic Cushing's syndrome

\section{Background}

Congenital adrenal hyperplasia $(\mathrm{CAH})$ is an autosomal recessive disorder caused by the loss or severe decrease in activity in one of the steroidogenic enzymes involved in cortisol biosynthesis. The majority of cases are caused by 21-hydroxylase deficiency (21-OHD) [1-3], followed by $11 \beta$-hydroxylase deficiency (11ß-OHD) in Jews of

\footnotetext{
* Correspondence: Iulin88@sina.com

'Department of Endocrinology, Peking Union Medical College Hospital, Chinese Academy of Medical Science and Peking Union Medical College, Key Laboratory of Endocrinology of National Health Commission of the People's Republic of China, No. 1 Shuaifuyuan, Dongcheng District, Beijing 100730, China

Full list of author information is available at the end of the article
}

Moroccan origin, people of Turkish descent, and Han Chinese. In the general Caucasian population, it has a prevalence of $5-8 \%$ and occurs in approximately $1: 100,000$ to $1: 200,000$ of live births [4-7].

The 11ß-hydroxylase converts 11-deoxycortisol and 11-deoxycorticosterone (DOC) to cortisol and corticosterone, respectively, and it is regulated by the adrenocorticotropic hormone (ACTH) secreted by the pituitary gland. A deficit of $11 \beta$-hydroxylase, however, causes decreased production of cortisol, accumulation of steroid precursors and an overproduction of androgens. Therefore, the classical form of $11 \beta-O H D$ is characterized by genital ambiguity in female patients [4] and precocious

(C) The Author(s). 2018 Open Access This article is distributed under the terms of the Creative Commons Attribution 4.0 International License (http://creativecommons.org/licenses/by/4.0/), which permits unrestricted use, distribution, and 
puberty, rapid somatic growth and bone age acceleration in both genders as a result of hyperandrogenemia. Hypertension occurs in approximately two-thirds of these patients because of the accumulation of steroid precursors, primarily deoxycorticosterone. In contrast, this symptom is not seen in patients with 21-OHD.

The $11 \beta-O H D$ is caused by the mutation of the $11 \beta$-hydroxylase gene (CYP11B1), which is located on chromosome 8q21. This gene contains 9 exons, approximately 40 kilobases apart from the highly homologous aldosterone synthase gene $(C Y P 11 B 2)[8,9]$. Herein, we first report the observation of classic features with two novel mutations genetically confirmed for $11 \beta-O H D$ in a Chinese family.

\section{Case presentation}

The patient was born after a full-term delivery by natural labor, and his parents had a non-consanguineous marriage. A large phallus and skin hyperpigmentation were observed at birth. He presented with deep voice and accelerated growth rate at the age of 12 months. At 6.5 years, the appearance of pubic hair was reported. He was admitted to a pediatric hospital at the age of 7.3 years. His height was $144.5 \mathrm{~cm}$ (+ 3.6 SDS, according to the 2009 height standardized growth chart for Chinese children and adolescents aged 2 to 18 years old). He presented with more dark skin, a larger phallus, advanced bone age, and high blood pressure $(160 / 100 \mathrm{mmHg})$. A laboratory investigation showed the following results: potassium $3.06 \mathrm{mmol} / \mathrm{L}$; sodium $142.1 \mathrm{mmol} / \mathrm{L}$; testosterone more than $750 \mathrm{ng} / \mathrm{dL}$; follicle stimulating hormone (FSH) $27.2 \mathrm{mIU} / \mathrm{ml}$; luteinizing hormone (LH) $4.2 \mathrm{mIU} / \mathrm{ml}$; morning serum cortisol $1.1 \mu \mathrm{g} / \mathrm{dl}$; and adrenocorticotropic hormone (ACTH) $673 \mathrm{pg} / \mathrm{ml}$ (Table 1). A computed tomography scan showed bilateral adrenal enlargement, as shown in Fig. 1a. He was diagnosed with congenital adrenal hyperplasia resulting from $11 \beta-O H D$ and began the dexamethasone treatment. After taking dexamethasone, the patient achieved normal sodium and potassium and decreased blood pressure (130/ $80 \mathrm{mmHg}$ ).

The patient took dexamethasone $0.75 \mathrm{mg} / \mathrm{d}$ for more than 10 years without follow-up or dose titration, and gradually developed symptoms of weight gain, round face, ecchymoses, striae, acne, hyperuricemia, and recurrent tinea corporis. Additionally, his blood pressure rose to $150 / 100 \mathrm{mmHg}$. He reached his final adult height at 8 years old $(148 \mathrm{~cm},+3.2$ SDS $)$. The patient was referred to our hospital with the complaint of short stature when he was 19 years old $(148 \mathrm{~cm},-4.0 \mathrm{SDS})$. At this visit, he presented with blood pressure of $160 / 120 \mathrm{mmHg}$, a body

Table 1 Biochemical and hormonal findings of the patient before and after treatment with glucocorticoid

\begin{tabular}{|c|c|c|c|c|c|}
\hline Biochemical and hormonal findings & 13 years ago & On admission & 1 month later & 4 months later & Normal values \\
\hline Treatment & Before treatment & $\begin{array}{l}\text { Dexamethasone } \\
(0.75 \mathrm{mg} / \mathrm{d})\end{array}$ & $\begin{array}{l}\text { Prednisone } \\
(7.5 \mathrm{mg} / \mathrm{d})\end{array}$ & $\begin{array}{l}\text { Prednisone } \\
(7.5 \mathrm{mg} / \mathrm{d})\end{array}$ & \\
\hline $\mathrm{Na}^{+}(\mathrm{mmol} / \mathrm{L})$ & 142.1 & 137 & 138 & 135 & $135-145$ \\
\hline $\mathrm{K}^{+}(\mathrm{mmol} / \mathrm{L})$ & 3.06 & 5.0 & 4.0 & 4.7 & $3.5-5.5$ \\
\hline $\mathrm{Cl}^{-}(\mathrm{mmol} / \mathrm{L})$ & - & 102 & 103 & 100 & $96-111$ \\
\hline$P(n g / m l)$ & - & 0.16 & 0.21 & 0.37 & $0.10-0.84$ \\
\hline 17-OHP (ng/ml) & - & 1.66 & 1.45 & 2.32 & $<0.7-2.5$ \\
\hline $\mathrm{T}(\mathrm{ng} / \mathrm{ml})$ & $>750 \mathrm{ng} / \mathrm{dl}^{\mathrm{a}}$ & 2.33 & 2.51 & 3.13 & $1.75-7.81$ \\
\hline DHEA-S $(\mu \mathrm{g} / \mathrm{dl})$ & - & 26.9 & 25.2 & - & $24-537$ \\
\hline $\mathrm{E}_{2}(\mathrm{pg} / \mathrm{ml})$ & - & $<5$ & 31 & 35.0 & $<47$ \\
\hline $\mathrm{LH}(\mathrm{IU} / \mathrm{L})$ & 4.2 & 5.08 & 5.02 & 3.68 & $1.24-8.62$ \\
\hline FSH (IU/L) & 27.2 & 8.85 & 5.76 & 4.73 & $1.27-19.26$ \\
\hline Cortisol at 8 AM $(\mu \mathrm{g} / \mathrm{dl})$ & 1.1 & - & 1.24 & - & $5-25$ \\
\hline ACTH at 8 AM $(p g / m l)$ & 673 & $<5$ & 24.8 & 12.5 & $0-46$ \\
\hline PRA upright (ng/ml/h) & 0.005 & 8.27 & 2.26 & - & $0.93-6.56$ \\
\hline AT-II upright (pg/ml) & 82.14 & 112.18 & 94.09 & - & $25.3-145.3$ \\
\hline Aldo upright (ng/dl) & 6.16 & 13.24 & 6.73 & - & $6.5-29.6$ \\
\hline UA $(\mu \mathrm{mol} / \mathrm{L})$ & - & 706 & 730 & 620 & $210-416$ \\
\hline $\mathrm{TC}(\mathrm{mmol} / \mathrm{L})$ & - & 6.21 & 5.42 & 6.04 & $2.85-5.70$ \\
\hline $\mathrm{TG}(\mathrm{mmol} / \mathrm{L})$ & - & 2.17 & 1.25 & 1.20 & $0.45-1.70$ \\
\hline $\mathrm{HDL}-\mathrm{C}(\mathrm{mmol} / \mathrm{L})$ & - & 1.86 & 1.29 & 1.40 & $0.93-1.81$ \\
\hline LDL-C (mmol/L) & - & 3.67 & 3.58 & 3.79 & $<3.37$ \\
\hline
\end{tabular}

Endnote: ${ }^{\mathrm{a}} T=750 \mathrm{ng} / \mathrm{dl}=7.5 \mathrm{ng} / \mathrm{ml}$ (normal value $0-45 \mathrm{ng} / \mathrm{dl}$ ) 


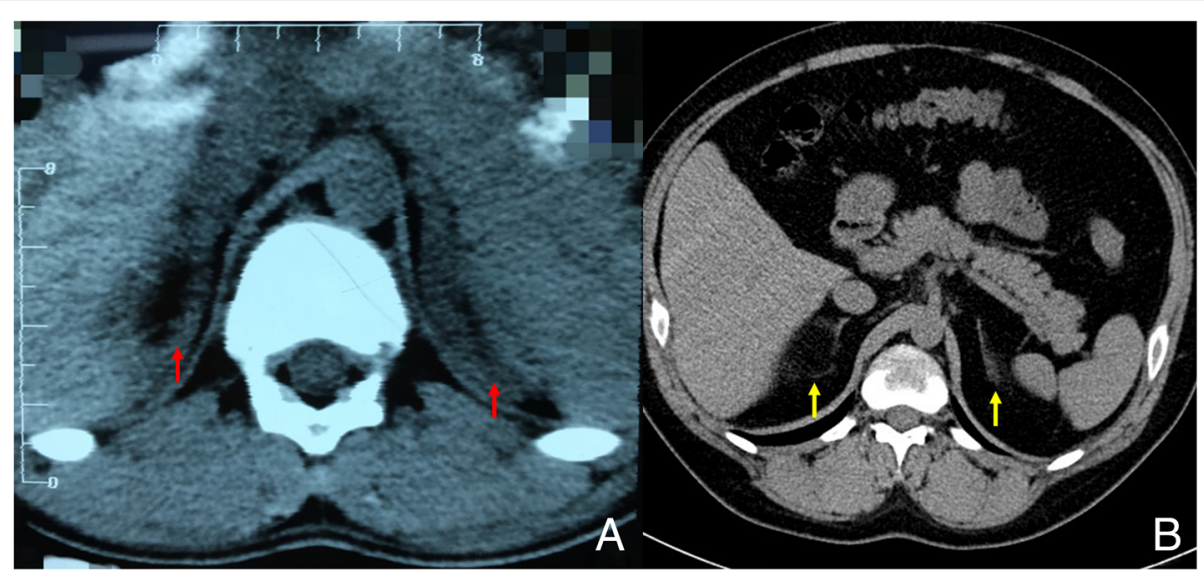

Fig. 1 Adrenal computed tomographic scan. a 13 years ago (age: 7 years, 3 months), before treatment, the scan revealed bilateral adrenal hyperplasia (red arrow). b On admission (age: 19 years), after treatment with dexamethasone, the scan showed bilateral adrenal atrophy (yellow arrow)

mass index (BMI) of $36.5 \mathrm{~kg} / \mathrm{m}^{2}$, and a waist circumference of $110 \mathrm{~cm}$, with the appearance of typical Cushing's syndrome with neck acanthosis nigricans (Fig. 2). The laboratory test results showed the following (Table 1): ACTH less than $5 \mathrm{pg} / \mathrm{ml}$; cortisol $1.24 \mu \mathrm{g} / \mathrm{dl}$; testosterone $2.33 \mathrm{ng} / \mathrm{ml}$; progesterone $0.16 \mathrm{ng} / \mathrm{ml} ; 17 \alpha$-hydroxyprogesterone $1.66 \mathrm{ng} /$ $\mathrm{ml}$; dehydro-epiandrosterone sulfate (DHEA-S) $26.9 \mu \mathrm{g} / \mathrm{ml}$; potassium $5.0 \mathrm{mmol} / \mathrm{L}$ and sodium $137 \mathrm{mmol} / \mathrm{L}$. A computed tomography scan revealed bilateral adrenal atrophy

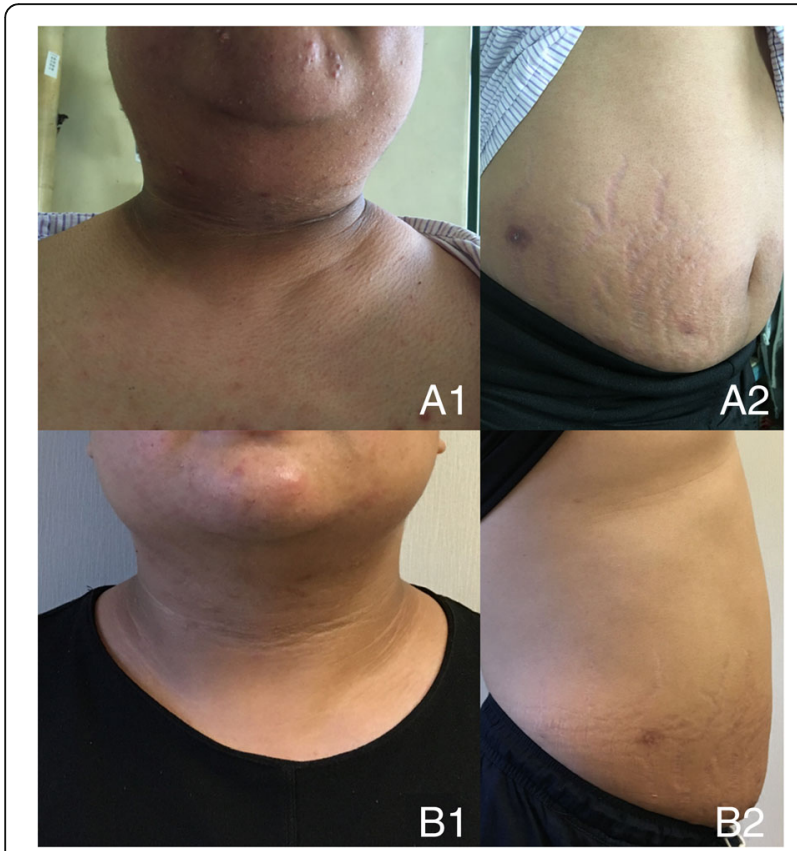

Fig. 2 General appearance of the patient. (A) At the neck, clavicle fat pad and acanthosis nigricans was found. (B) On his lower trunk, central obesity and striae were noted. (1) Before changing medication from dexamethasone to prednisone. (2) Four months after changing medication from dexamethasone to prednisone
(Fig. 1B). He was diagnosed with hyperinsulinemia, hyperuricemia, hyperlipidemia, and fatty liver. The patient was diagnosed with iatrogenic Cushing's syndrome. Due to significantly inhibition ACTH, elevated plasma renin activity, and bilateral adrenal atrophy, we speculated that the patient was deficient in mineralocorticoids. He stopped taking dexamethasone and began prednisone $(7.5 \mathrm{mg} / \mathrm{d})$. The patient was prescribed nifedipine controlled-release tablets $(60 \mathrm{mg} / \mathrm{d})$ and metoprolol succinate sustained-release tablets $(47.5 \mathrm{mg} / \mathrm{d})$, and his blood pressure was controlled at 138148/90-106 mmHg. Four months after switching from dexamethasone to prednisone, the patient came to our clinic for follow-up and had decreased body weight $(6 \mathrm{~kg})$, normal blood pressure $(120 / 70 \mathrm{mmHg})$, and normal serum potassium levels.

Written informed consent was obtained from the patient and his parents before the genetic investigation. CYP11B1 (NM_000497) gene was analyzed by direct sequencing using genomic DNA extracted from leucocytes of peripheral blood by EZNA Blood DNA Midi Kit (Atlanta, GA, US). Briefly, PCR was performed in a $20 \mu \mathrm{L}$ reaction volume containing $50 \mathrm{ng}$ of genomic DNA, $10 \mu \mathrm{L}$ of $2 \times \mathrm{GC}$ PCR buffer, $0.1 \mu \mathrm{M}$ of each dNTP, $0.1 \mu \mathrm{M}$ of each primer, and 1.25 units of rTaq polymerase (Takara, Shiga, Japan) in a thermocycler (ABI9700, US). For all of the amplicons, the genomic DNA was denatured at $94{ }^{\circ} \mathrm{C}$ for $10 \mathrm{~min}$, followed by 35 cycles of denaturation at $94{ }^{\circ} \mathrm{C}$ for $30 \mathrm{~s}, 60{ }^{\circ} \mathrm{C}$ for $30 \mathrm{~s}$, and $72{ }^{\circ} \mathrm{C}$ for $1 \mathrm{~min} 40 \mathrm{~s}$. The final extension was at $72{ }^{\circ} \mathrm{C}$ for $10 \mathrm{~min}$. To prevent amplification of highly homologous $C Y P 11 B 2$ sequences, the $C Y P 11 B 1$ gene was amplified in four fragments using four unique primer pairs (Additional file 1: Table S1: Primers used for PCR assay of CYP11B1 gene) [10, 11]. Amplified products were detected by agarose gel electrophoresis and sequenced using an ABI3730 DNA Analyzer (Applied Biosystems). Each individual was identified according to the sequencing results 
using SeqMan software. To predict the functional effects of novel mutations, the sequence alterations were assessed using in silico prediction algorithms in MutationTaster (an online program at http://www.mutationtaster.org, which automatically provides the probability for a variation to be either a pathogenic mutation or a benign polymorphism.

Analysis of the CYP11B1 gene disclosed two novel mutations (Fig. 3): a heterozygous in-frame insertion deletion mutation c.1440_1447delinsTAAAAG in exon 9 inherited from the father and a heterozygous mutation c.1094_1120delTGCGTGCGGCCCTCAAGGAGACCT

TGC (p.364_372del) in exon 6 inherited from the mother. These two novel frameshift mutations resulted in both amino acid sequences and splice site changes. Like the deletion mutation inherited from the mother, the mutation c.1440_1447delinsTAAAAG also prolonged the protein sequence. These two novel mutations were not observed in the Exome Aggregation Consortium (ExAC) or 1000 Genomes databases, indicating that the variants were rare. To further determine whether these two mutations were indeed potential pathogenic factors, the CYP11B1 sequence variations of c.1440_1447delinsTAAA AG and c.1094_1120delTGCGTGCGGCCCTCAAGGA GACCTTGC (p.364_372del) were both automatically predicted by MutationTaster to be disease-causing mutation (Table 2). In addition, we also identified two polymorphic loci in the patient's CYP11B1 gene at exon 1 (c.225A > G, p.Leu75Leu) and exon 2 (c.246C > T, p.Asp82Asp).

\section{Discussion and conclusion}

Clinical presentation, laboratory findings, and genetic features indicated the diagnosis of $\mathrm{CAH}$ resulting from $11 \beta-O H D$ in our patient, which appeared to be a compound heterozygote for two novel mutations in the CYP11B1 gene.

$11 \beta$-hydroxylase, one of the cytochrome P-450 enzymes, consists of 503 amino acids [12]. To date, a cluster of mutations have been reported, some of which affect the spatial conformation of $11 \beta$-hydroxylase to varying degrees, in particular to maintain the conformation of the key region of the enzyme activity [13-17]. Some mutations could change the reading frame, resulting in production of the wrong protein. If the premature termination appears in advance, the protein expression is terminated prematurely, causing the corresponding functional domain of the protein to change or disappear and the enzyme activity to be lost, accordingly [18-21].

In this study, we identified a novel mutation, c.1094_1120delTGCGTGCGGCCCTCAAGGAGACCT

TGC in exon 6, which resulted in the deletion of 9 amino acids at position 364_372 (p.364_372del). CYP11B1, a cytochrome P-450 enzyme, uses heme as a prosthetic group to catalyze redox reactions [22]. The

A

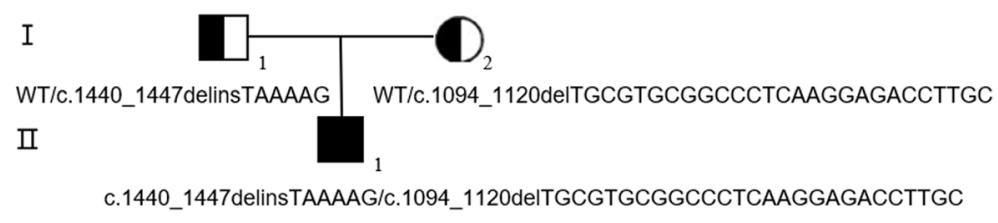

B

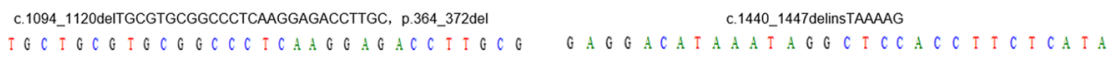

I.1
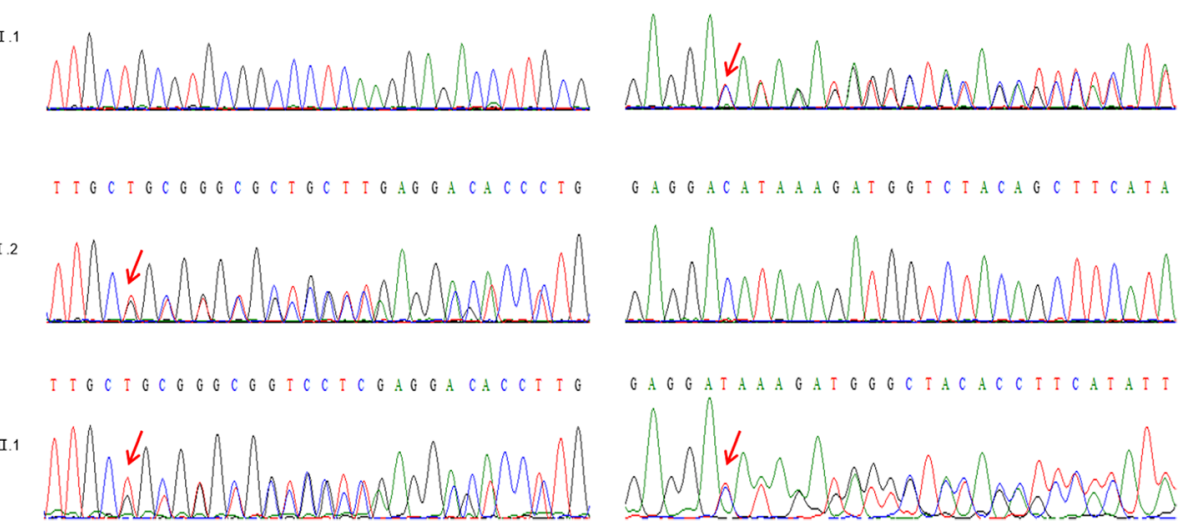

Fig. 3 Mutation analysis by direct DNA sequencing. a Pedigree illustrating the segregation of the mutant alleles to the index patient (II.1). b The left panel shows the deletion at c.1094_1120delTGCGTGCGGCCCTCAAGGAGACCTTGC, which results in the deletion of nine amino acids at position 364_372 (p.364_372del). The mother (I.2) and the patient (II.1) are heterozygous for c.1094_1120delTGCGTGCGGCCCTCAAGGAGACCTTGC mutation, whereas the father shows the wild-type sequence at this position. The indel mutation C.1440_1447delinsTAAAAG, leading to original stopcodon lost, results in elongated protein. The patient was found to be heterozygous for this mutation was found in the heterozygous state in the patient (II.1) and the father (I.1). The mother carries the homozygous wild-type allele at this position 
Table 2 Bioinformatics analysis of two novel mutations

\begin{tabular}{|c|c|c|c|}
\hline \multirow[t]{3}{*}{ Novel mutation } & \multicolumn{3}{|c|}{ Bioinformatics analysis } \\
\hline & \multicolumn{2}{|l|}{ MutationTaster } & \multirow{2}{*}{$\begin{array}{l}\text { Domain } \\
\text { Type }\end{array}$} \\
\hline & prediction & Score & \\
\hline c.1094_1120delTGCGTGCGGCCCTCAAGGAGACCTTGC, p.364_372del & disease causing & 0.999 & K-helix \\
\hline c.1440_1447delinsTAAAAG, original stop codon lost, results in prolonged protein & disease causing & 0.999 & C-term \\
\hline
\end{tabular}

MutationTaster Prediction: polymorphism or disease causing

three-dimensional structure of the protein shows that I-, $\mathrm{K}$-, and L-helixes contain a highly conserved heme-binding area [22]. The amino acid residues 364_372 constitute the putative K-helix of the CYP11B1 model [22]. The deletion of amino acid residues 364_372 may have resulted in defection of the K-helix. The side chain of R366 faces toward the protein surface, maintaining a positive surface charge. Additionally, the positive surface charge is involved in the CYP-Adx interaction, which is fundamental for CYP11B1 function [14]. A368 was located in a hydrophobic environment and interacted with the hydrophobic side chains of the amino acid residues V336 and L340 located in the J-helix [17]. The change in A368 resulted in a disorientation of the J-helix, I-helix, or K-L loop, containing a meander region and C450 coordinating the heme iron [17]. Changing this structure's orientation resulted in substantial changes of both the protein conformation and the heme group orientation relative to the enzyme [17]. E371 at the end of the K-helix might be located in the conserved central core of the P450 enzymes, and the protein domain around the conserved central core could be of fundamental importance [15]. We speculate that p.364-372 del could decrease or abolish CYP11B1 activity by preventing the formation of the K-helix, which in turn would affect the tertiary structure of the protein.

In addition, we also identified c.1440-1447 delins TAAA AG in exon 9, leading to the loss of original stop codon and resulting in an elongated protein. L487-A501 is conserved in humans, rats, and mice [22]. One study reported that the last 10 amino acids in the $\mathrm{C}$-terminal region of the CYP11B1 gene have little effect on CYP11B1 function [23]. It is not clear whether the $\mathrm{C}$-terminal protein elongation will affect the three-dimensional structure of the enzyme and thus reduce its activity. We speculate that the mutation of c.1440_1447delinsTAAAAG in exon 6 could be the primary cause of the $11 \beta-O H D$ in our patient. Combining in vitro expression studies with protein structure analysis is a powerful means of providing new insights in the understanding of structural-functional relationships.

The patient in this article took an unnecessarily high dose of dexamethasone over a long period without regular follow-up or dose adjustment, and he ultimately developed iatrogenic Cushing's syndrome and reduced final height. The treatment of $11 \beta-O H D$ is generally identical to that of 21-OHD. Glucocorticoid doses should be adjusted to reduce the risk of iatrogenic Cushing's syndrome and growth impairment, but stress doses of glucocorticoids are necessary in cases of acute illness [24, 25]. Monitoring with plasma DOC and plasma renin activity can be helpful. Additional antihypertensive treatment may be required if blood pressure remains elevated, despite optimal glucocorticoid treatment. Supplemental treatments to maintain the balance of electrolytes and blood pressure include spironolactone, amiloride, and calcium channel blockers [7, 24]. Since the renin-angiotensin system is suppressed in these patients, angiotensin-converting enzyme inhibitors and angiotensin receptor II blockers should be avoided.

The management of CAH can be complicated by iatrogenic Cushing's syndrome, inadequately treated hyperandrogenism, or both. Patients treated with supraphysiological doses of glucocorticoids not only experienced slowed growth but could also exhibit the signs and symptoms of iatrogenic Cushing's syndrome. Thus, we emphasized the importance of clinical follow-up. Close clinical monitoring of symptoms and signs, growth and development, and laboratory results are essential to optimize treatment outcomes.

In conclusion, our findings demonstrated the presence of the $11 \beta-O H D$ phenotype with two novel pathogenic mutations of the CYP11B1 gene in a Chinese patient. On the basis of our results, the outcome of this study has paved the way for a more efficient diagnosis and genetics counseling for diagnosis of patients with this disorder in China. Further research is required, however, to determine in vitro expression studies and protein structure analysis that may affect $11 \beta$-hydroxylase activity.

\section{Additional files}

\section{Additional file 1: Table S1. Primers Used for PCR Assay of CYP11B1} Gene. (DOCX 17 kb)
Abbreviations

11ß-OHD: 11ß-hydroxylase deficiency; 17-OHP: 17a-hydroxyprogesterone; 21-OHD: 21-hydroxylase deficiency; ACTH: Adrenocorticotropic hormone; Aldo: Aldosterone; AT-II: Angiotensin-II; BMI: Body mass index; $\mathrm{CAH}$ : Congenital adrenal hyperplasia; CYP11B1: 11ß-hydroxylase gene; CYP11B2: Aldosterone synthase gene; DHEA-S: Dehydro-epiandrosterone sulfate; DOC: 11-deoxycorticosterone; $E_{2}$ : estradiol; FSH: Follicle stimulating hormone; HDL-C: High-density lipoprotein cholesterol; LDL-C: Low-density lipoprotein cholesterol; LH: Luteinizing hormone; P: Progesterone; PRA: Plasma renin activity; T: Testosterone; TC: Total cholesterol; TG: Triglycerides; UA: Uric acid 


\section{Funding}

This study was supported by grants from the National Key Program of Clinical Science (WBYZ2011-873) and the National Key Research and Development Program of China (2016YFC0901500), which were mainly for the collection, genetic analysis, and interpretation of data.

\section{Availability of data and materials}

All data generated and analyzed during this study are included in this published article and are available from the corresponding author upon reasonable request. The two novel mutations are not observed in the ExAC and 1000 Genomes database.

\section{Authors' contributions}

LL, SC, HJZ, HP, ZLL, and XQW diagnosed the patient, provided follow-up, and acquired clinical data. JJ and ZHL completed the genetic analysis. LL and XXY conducted investigations, reviewed literature, drafted the manuscript, and reviewed the manuscript for final publication. All of the authors read and approved the final manuscript.

\section{Ethics approval and consent to participate}

The study was performed in accordance with the Declaration of Helsinki and was approved by Peking Union Medical College Hospital's Research and Ethical Committee (JS1233).

\section{Consent for publication}

Written informed consent was obtained from the patient and his parents, including the permission for details and images related to the patient and his parents to be published. The patient and his parents were informed that the details and images would be freely available on the internet and may be seen by the general public. Copies of the consent forms are available for review by the editor of this journal.

\section{Competing interests}

The authors declare that they have no competing interests.

\section{Publisher's Note}

Springer Nature remains neutral with regard to jurisdictional claims in published maps and institutional affiliations.

\section{Author details}

'Department of Endocrinology, Peking Union Medical College Hospital, Chinese Academy of Medical Science and Peking Union Medical College, Key Laboratory of Endocrinology of National Health Commission of the People's Republic of China, No. 1 Shuaifuyuan, Dongcheng District, Beijing 100730, China. ${ }^{2}$ The Key Laboratory of Genome Sciences and Information, Beijing Institute of Genomics, Chinese Academy of Sciences, Beijing 100101, China.

Received: 2 November 2017 Accepted: 13 September 2018

Published online: 21 September 2018

\section{References}

1. Witchel SF, Aston CE. The role of heterozygosity for CYP21 in the polycystic ovary syndrome. J Pediatr Endocrinol Metab. 2000;13(Suppl 5):1315-7.

2. Speiser PW, White PC. Congenital adrenal hyperplasia. N Engl J Med. 2003; 349(8):776-88. https://doi.org/10.1056/NEJMra021561.

3. Merke DP, Bornstein SR. Congenital adrenal hyperplasia. Lancet. 2005 365(9477):2125-36. https://doi.org/10.1016/S0140-6736(05)66736-0.

4. Zachmann $M$, Tassinari D, Prader A. Clinical and biochemical variability of congenital adrenal hyperplasia due to 11 beta-hydroxylase deficiency. A study of 25 patients. J Clin Endocrinol Metab. 1983;56(2):222-9. https://doi. org/10.1210/jcem-56-2-222.

5. Han B, Xue L, Fan M, Zhao S, Liu W, Zhu H, et al. Clinical and molecular manifestation of fifteen $170 \mathrm{HD}$ patients: a novel mutation and a founder effect. Endocrine. 2016;53(3):784-90. https://doi.org/10.1007/s12020-016-0957-y.

6. White PC, Curnow KM, Pascoe L. Disorders of steroid 11 beta-hydroxylase isozymes. Endocr Rev. 1994;15(4):421-38. https://doi.org/10.1210/edrv-15-4-421.

7. Peter M. Congenital adrenal hyperplasia. 11 beta-hydroxylase deficiency. Semin Reprod Med. 2002;20(3):249-54. https://doi.org/10.1055/s-2002-35389.

8. White PC. Steroid 11 beta-hydroxylase deficiency and related disorders. Endocrinol Metab Clin N Am. 2001;30(1):61-79.
9. Chua SC, Szabo P, Vitek A, Grzeschik KH, John M, White PC. Cloning of CDNA encoding steroid 11 beta-hydroxylase (P450c11). Proc Natl Acad Sci U S A. 1987;84(20):7193-7.

10. Xu L, Xia W, Wu X, Wang X, Zhao L, Nie M. Chimeric CYP11B2/CYP11B1 causing 11 beta-hydroxylase deficiency in Chinese patients with congenital adrenal hyperplasia. Steroids. 2015;101:51-5. https://doi.org/10.1016/j. steroids.2015.06.002 Epub 2015 Jun 9.

11. Chabre O, Portrat-Doyen S, Chaffanjon P, Vivier J, Liakos P, Labat-Moleur F Chambaz E, Morel Y, Defaye G. Bilateral laparoscopic adrenalectomy for congenital adrenal hyperplasia with severe hypertension, resulting from two novel mutations in splice donor sites of CYP11B1. J Clin Endocrinol Metab. 2000 Nov;85(11):4060-8

12. Kawainoto $T$, Mitsuuchi $Y$, Ohnishi $T$, Ichikawa $Y$, Yokoyama $Y$, Sumimoto $H$, et al. Cloning and expression of a cDNA for human cytochrome P-450aldo as related to primary aldosteronism. Biochem Biophys Res Commun. 1990;173(1):309-16.

13. Khattab A, Haider S, Kumar A, Dhawan S, Alam D, Romero R, et al. Clinical, genetic, and structural basis of congenital adrenal hyperplasia due to 11 beta-hydroxylase deficiency. Proc Natl Acad Sci U S A. 2017;114(10): E1933-40. https://doi.org/10.1073/pnas.1621082114.

14. Parajes S, Loidi L, Reisch N, Dhir V, Rose IT, Hampel R, et al. Functional consequences of seven novel mutations in the CYP11B1 gene: four mutations associated with nonclassic and three mutations causing classic $11\{$ beta\}-hydroxylase deficiency. J Clin Endocrinol Metab. 2010;95(2):779-88. https://doi.org/10.1210/jc.2009-0651.

15. Geley S, Kapelari K, Johrer K, Peter M, Glatzl J, Vierhapper H, et al. CYP11B1 mutations causing congenital adrenal hyperplasia due to 11 beta-hydroxylase deficiency. J Clin Endocrinol Metab. 1996;81(8):2896-901. https://doi.org/10. 1210/jcem.81.8.8768848.

16. Curnow KM, Slutsker L, Vitek J, Cole T, Speiser PW, New MI, et al. Mutations in the CYP11B1 gene causing congenital adrenal hyperplasia and hypertension cluster in exons 6, 7, and 8. Proc Natl Acad Sci U S A. 1993;90(10):4552-6.

17. Krone N, Grischuk Y, Muller M, Volk RE, Grotzinger J, Holterhus PM, et al. Analyzing the functional and structural consequences of two point mutations (P94L and A368D) in the CYP11B1 gene causing congenital adrenal hyperplasia resulting from 11-hydroxylase deficiency. J Clin Endocrinol Metab. 2006;91(7):2682-8. https://doi.org/10.1210/jc.2006-0209.

18. Ben Cl, Riepe FG, Kahloul N, Kulle AE, Adala L, Mamai O, et al. Two novel CYP11B1 mutations in congenital adrenal hyperplasia due to steroid 11 beta hydroxylase deficiency in a Tunisian family. Gen Comp Endocrinol. 2012; 175(3):514-8. https://doi.org/10.1016/j.ygcen.2011.12.017.

19. Xu C, Qiao J, Liu W, Jiang X, Yan F, Wu J, et al. Identification and functional characterization of a large deletion of the CYP11B1 gene causing an 11 beta-hydroxylase deficiency in a Chinese pedigree. Horm Res Paediatr. 2012:78(4):212-7. https://doi.org/10.1159/000342871.

20. Zhang M, Liu Y, Sun S, Zhang H, Wang W, Ning G, Li X. A prevalent and three novel mutations in CYP11B1 gene identified in Chinese patients with 11-beta hydroxylase deficiency. J Steroid Biochem Mol Biol. 2013;133:25-9. https://doi.org/10.1016/j.jsbmb.2012.08.011.

21. Soardi FC, Penachioni JY, Justo GZ, Bachega TA, Inacio M, Mendonca BB, et al. Novel mutations in CYP11B1 gene leading to 11 beta-hydroxylase deficiency in Brazilian patients. J Clin Endocrinol Metab. 2009;94(9):3481-5. https://doi.org/10.1210/jc.2008-2521.

22. Belkina NV, Lisurek M, Ivanov AS, Bernhardt R. Modelling of three-dimensional structures of cytochromes P450 11B1 and 11B2. J Inorg Biochem. 2001;87(4): 197-207.

23. Portrat S, Mulatero P, Curnow KM, Chaussain JL, Morel Y, Pascoe L. Deletion hybrid genes, due to unequal crossing over between CYP11B1 (11betahydroxylase) and CYP11B2(aldosterone synthase) cause steroid 11 betahydroxylase deficiency and congenital adrenal hyperplasia. J Clin Endocrinol Metab. 2001;86(7):3197-201. https://doi.org/10.1210/jcem.86.7.7671.

24. Bulsari $\mathrm{K}$, Falhammar $\mathrm{H}$. Clinical perspectives in congenital adrenal hyperplasia due to 11 beta-hydroxylase deficiency. Endocrine. 2017;55(1):19-36. https://doi. org/10.1007/s12020-016-1189-x

25. Nimkarn S, New MI. Steroid 11 beta- hydroxylase deficiency congenital adrenal hyperplasia. Trends Endocrinol Metab. 2008;19(3):96-9. https://doi. org/10.1016/j.tem.2008.01.002. 